\title{
ASIA-PACIFIC REGION IN THE ARCHITECTURE OF THE MODERN WORLD
}

\section{Djurayeva Gulrukh Mirjalolovna,}

PhD, D.Sc. student of the University of World Economy and Diplomacy, Uzbekistan Political Science E-mail:sonix0120@rambler.ru

Abstract: In recent years, it becomes apparent that East Asia and the APR are beginning to play an increasingly important role in the world economy and politics. It is that the center of world economic development is increasingly moving. The article describes the discussion of the problem of regional leadership and the "Chinese factor", in other words, the integration of the PRC as a global state into the world system. The interests of the United States, the PRC, Japan and Russia are also explored, which are associated with the real policy of these states in the region under consideration.

Keywords: Asia-Pacific region, international relations, foreign policy, regional cooperation, international security.

Today, the Asia-Pacific region is considered to be a territory that is developing vigorously, significantly different from other regions of the world. It is characterized by distinctive historical, cultural and religious traditions. The main players forming the strategic quadrilateral of forces in this region are China - USA - Japan - Russia.

By the beginning of the new century, the Asia-Pacific region had ranked third in terms of economic integration, second only to North America and Europe. It produces $60 \%$ of world GDP, 1/2 of world trade, 1/2 of foreign direct investment. The population of the region is $40 \%$ of the world's Social science and humanities

Generalization of scientific results 
population, according to researchers, even with a slight increase in China's share by $2020-2025$ years may be about $10 \%$ of world GDP, all this will allow China to take place among the three world leaders such as the US and the European Union ${ }^{1}$. This fact is confirmed by the CG.Brzezinski, noting in his recent book "Strategic vision: America and the global crisis" that China, mainly due to the huge size of the population and within the XXI century will overtake the US in overall economic indicators - estimates of the Carnegie endowment, it will happen by $2030^{2}$.

The rapid economic growth of the Asia-Pacific region began in the late XX century has allowed this part of the globe to the status of the leading geopolitical power cores; there are intertwined interests of the leading power centers. For example, until now, the phenomenal speed at which new industrial countries have achieved economic growth is considered to be phenomenal.

The peculiarity of modern interstate relations in the Asia-Pacific region is their unstable nature. Thus, the Asia-Pacific region is a unique region in which the end of the bipolar system has not significantly affected international relations. As a result, in the region continue to exist in socialist States such as China, North Korea, Vietnam, and Laos. At the same time continues to work the us-Japan security Treaty, the US military presence in South Korea, these military blocs like ANZUS and ANSUK.

What is the role of leading States, such as China, USA, Japan and Russia in this region? How do they interact within a political quadrangle? According to the CG.Brzezinski, in the near future, China, which claims to be a regional leader, and the United States, which is defending its leadership in the Pacific, will play a key role in this region. Japan and South Korea will traditionally be the main allies of the US in this region, although each of these countries has its own interests from this Union ${ }^{3}$. Despite the fact That Southeast Asia is more interested in regional partnership, however, the countries located here do not exclude the possibility of starting a dialogue with the United States, against the backdrop of the frightening strengthening of China. Given the circumstances, the United States and China have developed in this region is not very simple relations that may suffer due to economic disagreements. At the same time, neither side wants to allow each other's economic and political growth, and for this reason they are constantly holding each other back.

\footnotetext{
${ }^{1}$ The Future of Asia and Russia's Policy // Russia in Global Politics. March-April 2006, No. 2.

2 Brzezinski Zb. Strategic view: America and the global crisis. M.2014g. p.31

${ }^{3}$ Brzezinski Zb. Strategic view: America and the global crisis. M.2014g. p.31

Social science and humanities

Generalization of scientific results
} 
At present, there is no possible threat of any conflict in the Asia-Pacific region. However, there are a number of factors that can lead to serious conflicts. First of all, this is certainly the fact that the United States is present here as the main subject of international relations. The United States is cooperating with countries in the region not only in economic and political terms. The main attention is paid to the military component, as in the AsiaPacific region there is a huge number of US military bases, in addition, under the leadership of the United States there are several military alliances that supply weapons to the countries of the region. As a result, US military capabilities remain dominant in this part of the world. The main argument for the presence in the region of a large number of us military contingent in the opinion of the United States is the prevention of the emergence of various crisis phenomena, the protection of international Maritime communications, the fight against manifestations of terrorism and extremism, etc., that is, the implementation of measures aimed primarily at protecting their own interests of the United States ${ }^{4}$.

In order to maintain the favorable situation in the Asia-Pacific region, the United States in various ways strengthened the dialogue not only with Japan and South Korea, but also intensified its military ties with Singapore, the Philippines, Australia and New Zealand. The United States actively supports Taiwan in its struggle for independence, particularly in the area of armaments. All these steps of the us leadership are aimed at containing the ambitious aspirations of China, for this reason, the US considers the reduction in the near future of the number of us troops not only undesirable, but also unacceptable ${ }^{5}$. At the same time, the United States strongly opposes any increase in the volume of military efforts of the countries of the region and, first of all, Japan. The main goal pursued by the United States is to impose on Japan a one-sided foreign policy focused only on cooperation with the United States, and thus Japan should be content with its Alliance, provided that the leading role of the United States in the most promising geopolitical Asia-Pacific region is maintained.

However, despite the weight of us-Japanese relations, according to most researchers today they are not experiencing the best time. According to

\footnotetext{
${ }^{4}$ Kortunov S. Russia's National Interests in the Asia-Pacific Region / S. Kortunov / The Security of Eurasia. - 2008. - No. 1. - P. 197-220

5 Jorn Doseh, Manfred Mols. «International in the Asia-Pacific: New Patterns of Power, Interest and Cooperation». - Hamburg: LIT; - New York: St Martin's Press, 2000. 
Henry Kissinger and ZB.Brzezinski ${ }^{6}$, the new strategic partner of the United States in the Asia Pacific region is China.

With regard to the us military presence in the region, there are two approaches that are absolutely opposite in the direction. Proponents of the first approach believe that most APR States support the idea that the United States retains the positive role of a regional leader whose responsibilities include stabilization in the region. This is mainly due to the fact that many States in the region used and use the military and economic presence of the United States in the region to guarantee high rates of its own economic development. These are primarily new industrial countries.

Proponents of the second approach (mainly China and Russia) believe that through their military presence in the region, the United States is imposing its will on the countries located here and trying to take a Central place in the region, while strengthening its military reserve in the region. This position is not consistent with their vision of the future of the situation in the region and is due to their own growing ambitions.

Russia and the United States in the Asia Pacific region there are overlapping interests. For example, the United States and Russia support a peaceful solution to the problems existing in the region, including the solution of the problem of the Korean Peninsula, the problem of not sanctioning Japan's military independence, as well as the overgrowth of existing territorial disputes in the region in armed conflicts or wars.

The next cause of the threat to stability in the Asia-Pacific region is a rapidly developing China. On the role of China in the region, the opinions of researchers also differ. Thus, if according to some researchers, a strong China can become a guarantor of peace and stability in the region, another group of scientists believes that a strong China will increase political tension in the region, since it has hegemonic ambitions in foreign policy, as well as the possibility of starting a military confrontation with Japan, which can dramatically destabilize the situation in the region.

Today, China is implementing a very balanced foreign policy aimed at establishing friendly relations with the United States, taking into account the growing economic interdependence of the two countries. In the political sphere continue to exist differences, for example on the question of the political status of Taiwan, the issue of Tibet, etc. But overall, foreign policy strategy of China in the Asia-Pacific region finally announced and as a result

${ }^{6}$ Brzezinski Zb. Strategic view: America and the global crisis. M.2014g. p.35 
is quite contradictory. Thus, China may subject some actions of the United States to sharp criticism, and on the other hand, it may show uncertainty in matters related to the activation of its role in the SCO.

Russia's attitude towards China is not always clear. China's main danger to Russia is not China's foreign policy claims, but its internal instability. Russia is not interested in China's internal destabilization, because otherwise huge migration flows from China may flow into Russia, which will create certain inconveniences for Russia and its economy. In addition, Russia needs China to balance evenly with other regional and global power centers in the Asia-Pacific region, primarily with the United States.

For this reason, all Russia's security policy in the region does not contradict Chinese interests, although Russia in some cases uses China to obtain certain economic and political benefits for itself.

Russia's position on the Korean problem is unambiguous. As you know, today the Korean Peninsula remains the most explosive zone in the region. Various initiatives and proposals of the United States and the DPRK's neighboring countries to curtail the North Korean nuclear program have not been continued. The DPRK continues to develop its nuclear programme and continues to be of serious concern to the countries of the region. For its part, Russia leads the line to maintain contacts with the two Koreas. Russian policy towards the DPRK was formed in 1948 and is developing with varying success. In some periods it became more active, and in some periods it fell into decline. The next round in the strengthening of relations was marked in 2015, when Russia and North Korea declared a year of bilateral friendship, during which a number of political, economic and cultural meetings took place. Since the early 2000s, Russia has been trying to smooth out several provocations by North Korea and, to the extent of its capabilities, is holding back the growing tension in this region. After testing of ballistic missiles by Pyongyang in 2017, Russia has repeatedly stated that its strategy to maintain friendly relations with both South and North Korea aimed at finding a compromise on the issue of peaceful solution to the crisis on the Korean Peninsula7.

A thoughtful and balanced approach of Russia to the problem of the Korean Peninsula may become one of the main links aimed at peaceful settlement of the problems in this area of the Asia-Pacific region, in our view, this step would help Russia in the future to obtain some political and

7 Russia and North Korea: are real friends known in trouble ?. // https://inosmi.ru/politic/20180204/241361469.html 
economic benefits. At the same time, Russia must work together with other regional powers, including the United States, given Korea's possible reunification in the medium term. A unified Korea could become for Russia an important ally in the Asia-Pacific ${ }^{8}$.

The key problems of the modern Asia-Pacific region include the existence of various territorial disputes, among which it is advisable to distinguish the following:

Japan's territorial claims to the Republic of Korea (Takeshima island, Japan sea); Japan to China (Senkaku island, East China sea); China to Vietnam (Paracel Islands, South China sea).

Territorial dispute between Japan and Russia (Kuril Islands).

Territorial dispute between China, Vietnam, the Philippines, Malaysia and Taiwan over the ownership of the spratli archipelago.

The problem of the Asia-Pacific region is the lack of a clear structural design. The role of the main political mechanisms of political struggle has assumed various international and regional organizations such as the Shanghai cooperation Organization (SCO), ASEAN, CASST, OECD, NAFTA, MERCOSUR, East Asia forum. The analysis of these structures clearly reveals their main drawback, which is that relations in these organizations are unbalanced, characterized by the presence of one or two leaders-States around which all the other participants are consolidated. According to most analysts, in the near future, such APR countries as China, India, the United States, Japan and South Korea will not be able to establish any integration relations in the region, although it is possible to develop integration around the PRC, taking into account its implementation of the " soft powe » policy ${ }^{9}$.

Currently, two possible geopolitical forecasts have been developed for the development of events in the Asia-Pacific region.

The first scenario is developed by representatives of the American school headed by one of its bright representatives of ZB.Brzezinski. this scenario is aimed at containing China's power. As noted by the CG.China's Brzezinski policy in the Asia-Pacific region is aimed at ensuring that "...to dilute American power in the region to such an extent that weakened America felt the need to do using the regional influence of China as an ally, and eventually have China, which has become an influential world power as a partner. This goal should be pursued and it should be pursued in such a

\footnotetext{
8 See Kortunov S. Russia's National Interests in the Asia-Pacific Region / S. Kortunov / / The Security of Eurasia. - 2008. - No. 1. - P. 197-220

9 The Future of Asia and Russia's Policy // Russia in Global Politics. March-April 2006, No. 2. Social science and humanities

Generalization of scientific results
} 
way as not to spur the expansion of the us-Japan Alliance, nor the replacement of American influence in the Japanese region. ${ }^{10 "}$

It is difficult to argue that China is now developing rapidly, sometimes even at a rapid pace, and that it is likely that, over time, neither the US nor Japan will be able to confront it, and they will be forced to restrain it as far as possible through strategic cooperation. This fact will further strengthen China's role in the region and not exclude the possibility of some contradictions that could radically change the geopolitical situation in the region.

According to the second scenario, the strengthening of allied relations between the United States, Japan and Korea is expected, which may result in the emergence of a new United Korean state developing in the American direction. As a result of developments in this scenario, there will be a possibility of aggravation of contradictions in the Asia-Pacific region between the leading powers. Ultimately, this will strengthen the US role in the region and, as a response, Russia and China will be forced to engage in closer military-political cooperation to weaken us influence. Over time, there will be two spheres of influence - American-Japanese-Korean (Western) and SinoIndian-Russian (Eastern). Time will show how stable and secure such a confrontation will be, but in any case, the region will start the process of aggravation of the situation, which will ultimately have a negative impact on all countries located in the Asia-Pacific region.

${ }^{10}$ Brzezinski Zb. Strategic view: America and the global crisis. M.2016g. p.91 


\section{References:}

1. The Future of Asia and Russia's Policy // Russia in Global Politics. March-April 2006, No. 2.

2. Brzezinski $\mathrm{Zb}$. Strategic view: America and the global crisis. M.2016g. p.31

3. Kortunov S. Russia's National Interests in the Asia-Pacific Region / S. Kortunov // The Security of Eurasia. - 2008. - No. 1. - P. 197-220.

4. Jorn Doseh, Manfred Mols. «International in the Asia-Pacific: New Patterns of Power, Interest and Cooperation». - Hamburg: LIT; - New York: St Martin's Press, 2000.

5. Russia and North Korea: are real friends known in trouble ?. // https://inosmi.ru/politic/20180204/241361469.html

6. The Future of Asia and Russia's Policy // Russia in Global Politics. March - April 2006, No. 2; Utkin A. I. The Big Eight: the price of entry. Moscow: Algorithm, 2006. - P. 449. 